\title{
Mahua Biodiesel: An Alternative to Conventional Diesel Fuel
}

\author{
Yogendra Rathore ${ }^{1}$, Dinesh Ramchandani ${ }^{2}$

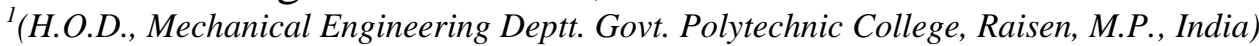 \\ ${ }^{2}$ (Assistant Professor, Mechanical Engineering Department, SISTec, Bhopal, M.P., India) \\ ('yogendra_ap@yahoo.com, ${ }^{2}$ dvramchandani@gmail.com)
}

\begin{abstract}
Energy is the basic need to any nation's growth. Due to energy crisis whole universe is struggling with many issues like fossil fuels are losing ground drastically, demand for energy is ever increasing, concerns to the climate changes \& high energy prices are putting us on our toes in the search of alternative and cleaner fuel sources which is the biggest challenge to the energy industry \& various nations. As a substitute of conventional diesel fuel, biodiesel fuel is made from renewable resources and it also has non toxic and biodegradable nature. Our country i.e. INDIA has many potential for the production of biodiesel from the seeds of edible and non edible oils. Out of many variants of oil seeds, only some variants are tested till the time. Many researchers studied on the properties part of biodiesel fuel that has shown that it is completely miscible with conventional diesel fuel. A unique property of biodiesel over conventional diesel fuel is that biodiesel releases particulate matter and gases. Amongst the potential sources of non edible oils of India, Mahua has shown very bright prospects. This paper shows the past and current progress along with other types of biodiesels, the characteristics, processing and economics available to Biodiesel industry and also it's their respective application part to automotive industry. The current paper fairly shows the studied comparison of conventional diesel fuel and Mahua biodiesel usage in view of its performance and exhaust characteristics parameters.
\end{abstract}

Keywords: biodiesel, transesterification, mahua oil, performance, emission, energy, policy.

\section{.I. INTRODUCTION}

A century before, Rudolf diesel first came with the concept of diesel engine, used peanut oil (vegetable oil) for experimental evaluation, that time only it indicated that vegetable oils are appropriate to cater the needs of future. In today's century, it is assumed as per the usage data of conventional petroleum fuels that it will become very scarce \& expensive to locate and manufacture, although researchers have found number of ways to increase the fuel economy but population of nations has increased many folds and also energy is the backbone of any nation's economy. Extreme exploration of crude oil deposits has been used in much type of usages, just because of sudden bursting of population around the globe. Lubricants that are in regular usage, made from mineral oils and additives which are very poisonous to water \& soil due to its respective denser chemical composition and lesser biodegradability. There is always an alarming situation as far as environment is concern which pulls our attention towards natural counter parts just because of rising crude prices, inappropriate disposal methods and absence of lubricant usage across the globe [1-3].

Fuels are very important to all of us in many ways due to its useful energy which we received during its combustion and satisfy many parameters of day to day life like transportation of public and supplies. Fossil fuel provides us major boon of energy which are petroleum oil, coal and natural gas. Today fuels from fossils carries $80 \%$ of the total energy requirement, also many of the industries using diesel engines are totally dependent for its manufacturing reason. Transport sector consists of busses, trucks, cars, ships etc consuming major amount of diesel and gasoline. This way we are totally dependent on this type of source of energy to the great extent where as growing demands of population possibly will not be fulfilled by household production of raw oil. [4-5].

Fossil fuels are derivatives of plant and animal fossils that are million years' old which lies in non renewable energy sources category. The demand for energy and fuel price will never be in the declining graph. Developing countries are totally dependent on fossil fuel for their growth and development but regrettably these will be consumed in next 65 years. Emission from the combustion of fossil fuel leads to pollution in atmosphere and global warming [6-9]. Many nations are facing such pressure from outside of national territory to work on issues of global warming [10-12]. Due to these every nation is looking for clean, green and renewable alternate fuel to address the today's and tomorrow's need. 


\subsection{PETRO-DIESEL \& BIO-DIESEL}

\section{LITERATURE REVIEW}

Petroleum diesel/petro-diesel/fossil diesel can be produced when fractional distillation of crude oil occurs between the temperature of $2000 \mathrm{C}$ and $3500 \mathrm{C}$ with pressure of atmosphere which produces a combination of chains of carbon that carries per molecule around 8 to 21 atoms of carbon. This is particular liquid fuels which were found by fractional distillation of crude oil which is commonly called petroleum diesel [13]. Whereas animal or vegetable oil based diesel fuel is known as Biodiesel which burns and emits very less soot, oxides of carbon and particulate matter [14]. It has long chain mono-alkyl esters and can be produced by transesterification of either vegetable oil or animal fat. The process will happen when one mole of triglyceride reacts with three moles of alcohol so as to manufacture one mole of glycerine and three moles of mono alkyl esters which is also termed as Biodiesel. This carries a long chain of mono alkyl esters and could be manufactured by doing transesterification of either vegetable oil or animal fat. The reaction can be done with one mole of triglyceride reacting with three moles of alcohol. Transesterification reaction is shown in figure 1. Biodiesel is like petroleum diesel fuel consists of chains of hydrocarbons which carry neither sulphur nor any of the aromatic compounds in its composition. It is also a kind of fuel which is of renewable natusre means that burns with less effect to environment in comparison with petro-diesel.

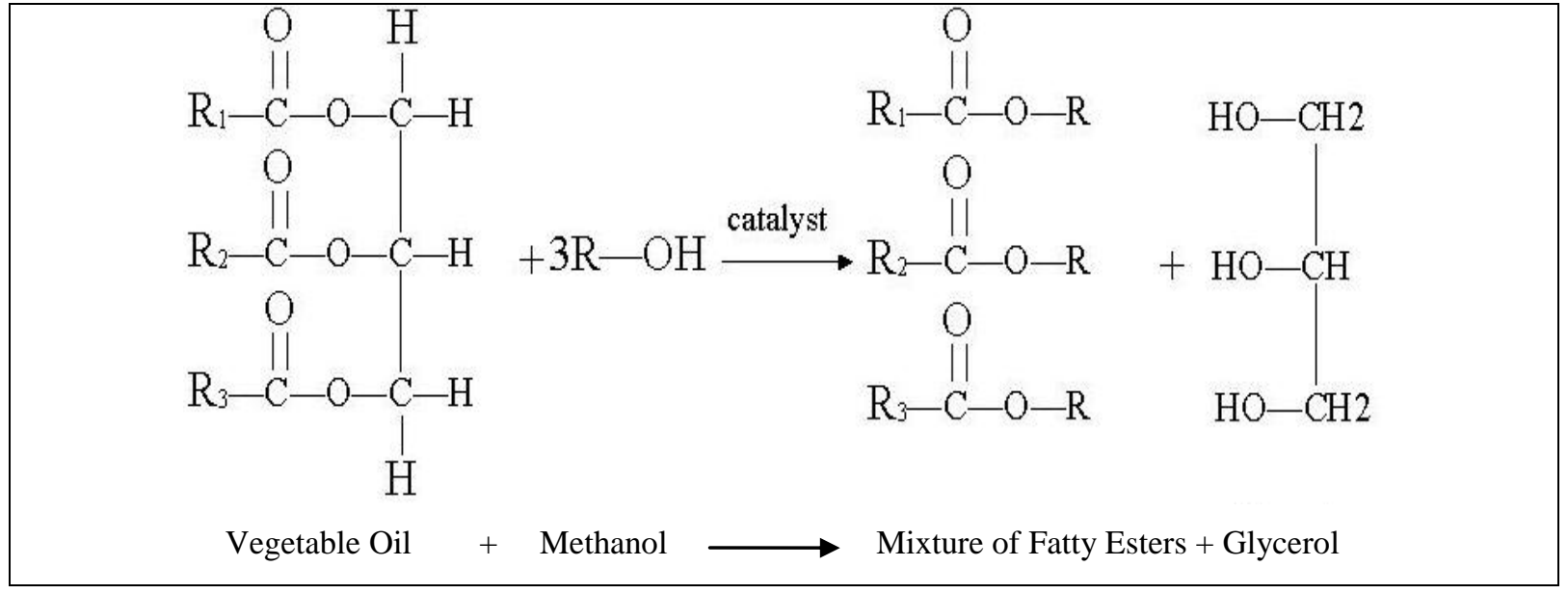

Fig. 1. Transesterification Reaction

\subsection{ADVANTAGES \& DISADVANTAGES OF BIODIESEL}

Biodiesel is a kind of fuel which is atmospherically pleasant and renewable and that is the main quality which has got all the appreciation all around the world. The merits with biodiesel as fuel are discussed as follows:

- Its emissions are not dangerous to our atmosphere.

- It is being capable of being agriculture, non-hazardous and recyclable and a renewable fuel.

- It carries high cetane number, low in sulphur content, low in volatility and availability in oxygen atoms per molecule of fuel.

- Use of biodiesel would create high job opportunities in developing countries in view of sector of agriculture where currently level of employment is very low [15].

Whereas the disadvantages of using biodiesel are listed as follows:

- It has high nitrogen oxides in emissions which results the formation of smog and acid rain.

- In view of comparison between the output in energy amongst biodiesel and petroleum diesel, requirement of biodiesel is relatively high for producing same amount of energy.

- Usage of precious farming land for biodiesel crop cultivation would result in increase in food cost all around and also could increases scarcity of food as well. 


\subsection{CURRENT SCENARIO}

Thus, in terms of end usage, energy demand across the transport sector is greatest. Roads, being one of the dominant infrastructures for transport, carry as estimated 85 to 90 Percent of the country's passenger traffic and 65 percent of its freight. Traffic on roads is growing at the rate of 7 to 10 percent per year; while the vehicle growth is of the order of 8 to 10 percent per year. In view of demand of petrol in comparison with diesel, diesel is five times demanded than petrol. India ranked fifth for consumption of primary energy and fourth as consumer of petroleum products and landing after ranking of U.S., China and Japan.

During last ten years, production of biodiesel has reached creditable figures which shows the increase in demand and its continuous increase in production figures are shown in Fig. 2 [16]. The escalation in the economy of India during 2009-10 is 8\% as on 31 Jan 2011; during 2010-11 it is 8.6\% as on 07 Feb 2011 [17].

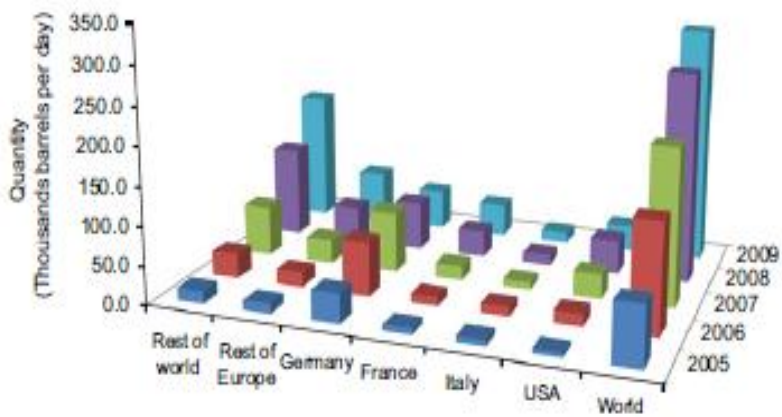

Fig. 2. Production of biodiesel in world [16].

The equation of rising demand in oil sector against production levels (Fig. 3) showing increase in dependency on imports to meet the total demand [18].

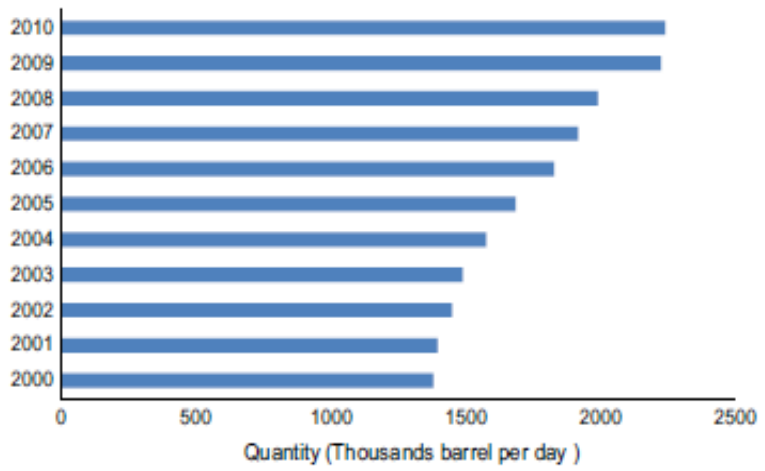

Fig. 3. Differentiation between production and consumption figures of oil in India [18].

India is one of the top 10 oil consuming countries in the world. The country's existing annual crude oil production is at about 32 million tonnes as against the demand of about 110 million tonnes [19]. In India, bulk of the freight (over 60\%) and passenger traffic (over $80 \%$ ) is carried by road; and diesel and petrol contribute to $98 \%$ of the energy consumed in the transport sector[20]. Oil imports during April- May 2007 were valued at US\$ 9165.20 million and the oil import bill is expected to rise to \$120 billion in 2011-2012 [21]. This fact is well established by the production and import data of edible oil (Fig. 3) [22]. It is estimated that proportionate consumption of petroleum products in India are as follows:-

India is listed in world's top 10 oil consuming nations. Our crude oil production figure in a year is around 32 million tonnes against the demand of around 110 million tonnes [19]. In our nation, freight includes $60 \%$ plus and passenger includes $80 \%$ plus is carried by road and collectively diesel and petrol figures around 
$98 \%$ of the energy is utilized in transport sector [20]. Imports of oil durig April-May 2007 were calculated as US\$ 9165.20 million and import of oil is expected to increase to \$120 billion in 2011-12 [21].

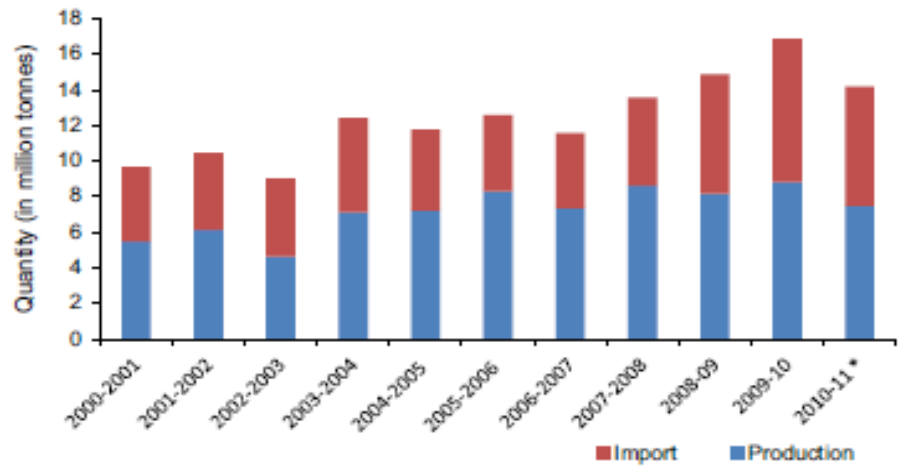

Fig. 4. Production and Import of edible oil in India [22].

\author{
Transport (Petrol, Diesel, CNG, and Aviation Fuel) \\ Industry (Petrol, Diesel, Fuel Oil, Naphtha, Natural Gas) \\ Commercial and Others \\ Domestic (LPG and Kerosene) \\ Agriculture (Diesel)
}

$$
\begin{aligned}
& : 51 \text { percent } \\
& : 14 \text { percent } \\
& : 13 \text { percent } \\
& : 18 \text { percent } \\
& : 4 \text { percent }
\end{aligned}
$$

That's why in regards of usage, demand of energy is greatest amongst transport sector. Roads are very important parameter in nation's infrastructures for transport which is $85-90 \%$ in passenger \& $65 \%$ in freight. Growth in road's traffic and vehicle growth is $7-10 \%$ and $8-10 \%$ every year respecitively.

\section{MAHUA}

The properties like high oiliness, viscosity and indices, higher flash points, less evaporative loss and low full accounting cost (includes operational and nature replenishment cost) are technical in nature which gives competitive edge and hence they are preferred even after some inferior traits like reduced oxidation and thermal stabilities, poor cold flow properties, lower shelf life, but researches are working on these parameters and can be improved by applying some modification in techniques and systematized research [23-27]. There is large numbers of varieties in oil (Edible \& Non Edible), only some are short listed as far as their potential is concern. Edible oils are used by all the population because of their food dependency, some non edible oils are also useful for food but mostly are not used and hence has low usage in food and hence low dependency as far as food parameter is concern that's why due to this only non edible oils could be utilized as alternative fuels having untapped potential and also multiply to the rural economy. Even after showing promising benefits very few attempts have been taken by previous researchers [28-32]. Non edible oils are the main source of making biodiesel in India and Mahua is taken as probable oil seed feed stock for the production of biodiesel. [33-34].

\section{$3.1 \quad$ MAHUA LITERATURE}

In India, we can find Mahua plant in many states like Orissa, Chattishgarh, Jharkhand, Bihar, Madhya Pradesh and Tamil Nadu and for getting successfully mature. It uses waste and dry land which is not at all useful for any kind of other vegetation. Its plant does not require any special or specific kind of attention as it is easily adaptable in any weather condition, resulting maximum height attains $20 \mathrm{~m}$, wide spreading roots and branches along with circular crown \& nice appealing structure. Fruits look like egg shaped berries and mature seeds can be drawn from June to July [35]. Moving ahead to its plantation part, its tree have been very useful in Indian economy, mostly carries the rural one. Season of flower ranges from February to April, rich in sugar content (73\%) just next to cane molasses. It also carries basic raw material for alcohol fermentation and in one tonne of 
its dried flower carries 450 liters of alcohol yield. $50 \%$ of oil contained by kernel of mahua fruit and its fresh oil is yellow in color where as its commercial oil is normally greenish yellow in color. The mahua tree takes 8 to 15 years to become mature and can draw fruits up to 60 years of age. As discussed it has highly spreaded roots which withholds the soil and all these happens on waste land which helps our rural people to grow along with national economy [36].

\subsection{MAHUA BOTANICAL FEATURES}

The botanical name is Madhuca Indica which represents the Sapotaceae family with common names as

Sanskrit:

Andhra Pradesh:

Madhuka

Gujarat:

Yappa

Hindi:

Mahuda

Karnataka:

Mahua, Mohwa,

Kerela:

Hippe

Maharashtra:

Ponnam

Orissa:

Mahwa

Tamil Nadu :

Mahula, Moha

West Bengal:

Illupei

English:

Mahwa, Maul

Butter tree.

A deciduous tree, 10 to $15 \mathrm{~m}$ tall and with a spreading, dense, round, shady canopy. Bark is rough, brown in colour, slightly cracked and fissured, inner bark red, exudes white, milky sap when cut. Leaves elliptic, $15-25 \times 8-15 \mathrm{~cm}$, tip pointed, base angled, texture thick, hairy beneath, nerves strong, about 12 pairs, tertiary nerves oblique, and margin entire but may be wavy. Stalk $2-4 \mathrm{~cm}$, reddish. Flowers in bunches at the end of the branches, white, $2 \mathrm{~cm}$ long, pointed, sweat scented, fleshy. Fruits ovoid, fleshy, 2-4cm across, greenish, 1-4 seeded. Seeds elongate, $2 \mathrm{~cm}$ long, brown shining [36].

\subsection{MAHUA AS FUEL}

As far as Mahua's fuel property are concerned it is comparable with diesel fuel and is available in good quantities that too underutilized. Its calorific value is $96.30 \%$ on volume basis of diesel. It does not have any significant change if we mix mahua oil by $20 \%$ in diesel in terms of power output, brake specific fuel consumption and brake thermal efficiency. By using mahua oil blends, performance of engine improved which enhance compression ratio from 16:1 to 20:1. With above results it is found that mahua oil can be treated as substitute of diesel but with proper care and can show profitability when it could be taken to large scale production. Table 1 Shows the characteristics of fat $\&$ Table 2 Shows the fuel properties of Mahua oil and Diesel. Stage wise concern is required like in sowing season along with latest agro techniques, proper pest control and post harvesting management [36].

TABLE 1. Characteristics of Fat [36]

\begin{tabular}{|c|l|l|}
\hline S. No & Characters & Characteristic / valve \\
\hline 1 & Colors & Pale Yellow \\
\hline 2 & Consistency & Plastic \\
\hline 3 & Refractive Index at 40 degree & C1.451 to 1.463 \\
\hline 4 & Specific gravity at 15 degree & C 0.857 to 0.871 \\
\hline 5 & Iodine valve & 58.00 to 70.00 \\
\hline 6 & Specification valve & 188 to 195 \\
\hline 7 & Un specification valve & 1.00 to 3.00 \\
\hline
\end{tabular}


IOSR Journal of Mechanical and Civil Engineering (IOSR-JMCE)

e-ISSN: 2278-1684, p-ISSN: 2320-334X

TABLE II. Fuel properties of Mahua oil and Diesel [36]

\begin{tabular}{|c|l|l|l|l|l|}
\hline S. No & Properties & Unit & Diesel & $\begin{array}{l}\text { Mahua } \\
\text { Oil }\end{array}$ & IS Limits for Grade A and B diesel \\
\hline 1 & Specific Gravity & & 0.829 & 0.905 & \\
\hline 2 & Kinematic viscosity at & $\mathrm{C} \& \mathrm{~T}$ & & & \\
\hline 3 & 40 deg Celsius & & 2.45 & 37.19 & $2.0-7.5$ at $38^{\circ} \mathrm{C}$ grade A \\
\hline 4 & 80 deg Celsius & & 0.67 & 11.67 & $2.5-15.7$ at $38^{\circ} \mathrm{C}$ grade B \\
\hline 5 & Calorific Value & $\mathrm{mj} / \mathrm{kg}$ & 44.02 & 38.964 & \\
\hline 6 & Pour Point & ${ }^{\circ} \mathrm{C}$ & -5 & 15 & 6 max grade A 12-18 max grade B \\
\hline 7 & Flash Point & ${ }^{\circ} \mathrm{C}$ & 47.5 & 238.4 & 55 min grade A 66 min grade B \\
\hline 8 & Carbon Residue & $\%$ & 0.034 & 0.4216 & 0.2 max grade A 1.5 max grade B \\
\hline 9 & Ash Content & $\%$ & 0.0065 & 0.022 & 0.01 max grade A 0.02 max grade B \\
\hline 10 & Water Content & ${ }^{\circ} \mathrm{C}$ & Trace & Trace & 0.05 max grade A 0.25 max grade B \\
\hline 11 & $\begin{array}{l}\text { Distillation temperature } \\
\text { IBP }\end{array}$ & & Trace & 90 & \\
\hline 12 & $90 \%$ Recovery & & 365 & 285 & $366^{\circ} \mathrm{C}$ for grade A \\
\hline
\end{tabular}

\subsection{USES OF MAHUA}

Madhuca Indica oil is not properly utilized vegetable oil which is available in bulk in India. Properties of MI oil fuel are shown in the limits of specification of many countries and is comparable with pure diesel. Fuel properties of diesel, mahua oil and blends are comparable. The calorific value of mahua oil was found as $96.30 \%$ on volume basis of diesel. It was found that mahua could be easily substituted up to $20 \%$ in diesel without any significant difference in power output, brake specific fuel consumption and brake thermal efficiency. The performance of engine with mahua oil blends improved with the increase in compression ratio from 16:1 to 20:1. Based on this study, it has been observed [36].

\subsection{MAHUA YIELD}

If we think biodiesel as the industry we have to face feed stock supply as top challenge because producers are looking for such type of non-food crop that too from non-agricultural land means with cheaper feed stock. It can also sustain in any type of weather conditions that means it is matching all the requirements of the market. Mahua will yield at Maturity as high as +3 tons oil with proper nutrition, and irrigation. Table 3 shows approximate yield/hectare of Mahua oil. This is totally an extraordinary amount of oil from an agricultural crop [36].

TABLE III. Approximate Yield/hectare [17]

\begin{tabular}{|c|l|l|}
\hline S. No & Optimal yield & 10.0 tons \\
\hline 1 & Seed yield & 3.60 ton \\
\hline 2 & Oil (36\% of Yield) ton & 3.60 ton \\
\hline 3 & Biodiesel ton & US $\$ 250.0 / \mathrm{ha}$ \\
\hline 4 & Plantation cost & US $\$ 100.0 / \mathrm{ha}$ \\
\hline 5 & Maintenance cost & \multicolumn{2}{|l|}{} \\
\hline & UNDER COC TECHNOLOGY & US $1250.0 / \mathrm{ha}$ \\
\hline 6 & Crop cultivation \& care cost & 6.00 tons \\
\hline 7 & Oil Production &
\end{tabular}




\subsection{MAHUA OIL EXTRACTION \& PURIFICATION OF MAHUA OIL}

Mahua Oil extraction process can be done with or without seed coat; also if we choose appropriate and efficient oil extraction method, we can enhance the yield by more than 5\%. Like in case of Jatropha, by using mechanical de hulling system so as to take out coat of seed, we can get $10 \%$ increased yield. In cold pressing where temperature is less than $60^{\circ} \mathrm{C}$, up to $88 \%$ and in hot pressing where temperature is $110-120^{\circ} \mathrm{C}$, up to $90 \%$ efficiency is achieved. The solvent extraction method increases the efficiency till $99 \%$ but it carries disadvantage too, with the solvent extraction is that the quantity of phospholipids in solvent extracted oil is double as high as compared to pressed oil. It requires then a further step of oil de gumming before transesterification. Oil extraction methods are also being developed based on fermentation hydrolysis. In this process, cell walls of the oil plant seeds are destroyed followed by the release of the oil present within the cells [37]. Table 4 shows comparison of fatty acid and composition (\%) of various seed oil [38].

TABLE IV. Comparison of Fatty Acid Composition (\%) of Various Seed Oil [38]

\begin{tabular}{|c|c|c|c|c|c|c|}
\hline S. No. & Fuels & Palmitic Acid & Stearic Acid & Oleic Acid & Linoleic Acid & Arachidic Acid \\
\hline 1 & $\begin{array}{l}\text { Mahua } \\
\text { Seed Oil }\end{array}$ & $16-28.4$ & $20.00-25.00$ & $41.0-51.0$ & $10.00-14.00$ & $0-3.31$ \\
\hline 2 & $\begin{array}{l}\text { Cotton } \\
\text { Seed Oil }\end{array}$ & 20.00 & 2.00 & 35.00 & 35.00 & ---- \\
\hline 3 & $\begin{array}{l}\text { Coconut } \\
\text { Oil }\end{array}$ & $8.00-11.00$ & $1.00-3.00$ & $5.00-8.00$ & $0-1.00$ & $0-0.50$ \\
\hline 4 & $\begin{array}{l}\text { Karanja } \\
\text { Seed Oil }\end{array}$ & $3.74-7.92$ & $2.41-8.91$ & $44.51-71.34$ & $10.81-18.32$ & $2.21-4.72$ \\
\hline 5 & $\begin{array}{l}\text { Rape Seed } \\
\text { Oil }\end{array}$ & 1.51 & 0.41 & 22.0 & 14.3 & ---- \\
\hline 6 & $\begin{array}{l}\text { Castor } \\
\text { Seed Oil }\end{array}$ & 2.00 & 1.00 & 7.00 & 5.00 & ---- \\
\hline 7 & $\begin{array}{l}\text { Jatropha } \\
\text { Seed Oil }\end{array}$ & $12.00-17.0$ & $5.00-9.50$ & $37.5-63.5$ & $19.0-41.0$ & 0.31 \\
\hline
\end{tabular}

\subsection{PROPERTIES OF MAHUA OIL}

Table 5 Shows Comparative Data of Mahua oil with oils of Different Origin \& Pure Diesel.

TABLE V. shows properties of Mahua oil \& its comparison

\begin{tabular}{|c|l|c|c|c|c|}
\hline S. No. & Properties & Diesel & Mahua Oil & Jatropha Oil & Karanja Oil \\
\hline 1 & $\begin{array}{l}\text { Calorific value } \\
{[\mathrm{MJ} / \mathrm{kg}]}\end{array}$ & 42.9 & 39.3 & 39.12 & 38.11 \\
\hline 2 & Density $[\mathrm{kg} / \mathrm{m} 3]$ & 841 & 911 & 879 & 88.6 \\
\hline 3 & Viscosity [cSt] & 3.62 & 5.91 & 4.77 & 5.82 \\
\hline 4 & Flash Point [oC] & 63.5 & 130.5 & 163 & 190.5 \\
\hline 5 & Fire Point [oC] & 75.5 & 146.5 & 176 & 192.5 \\
\hline
\end{tabular}




\section{ECONOMIC EVALUATION \& POTENTIAL RETURNS}

To become environmentally sustainable fuel, it must have three criteria that are social, technical and commercial. In Northern India i.e. in Bihar, Madhya Pradesh and Orissa, rural people are getting 40\% economy which is based on mahua seeds and flowers. Its tree requires little attention when root is nicely holding the soil; seed gives yield from 20 to $200 \mathrm{~kg} /$ tree annually and it has its own socio-economic value. On the commercial platform these trees can be planted on either of the road sides, railway tracks, canal banks or any other tribal/rural areas. In many countries researchers have found that Madhuca Indica Oil has properties within biodiesel limits, hence it can be termed as renewable fuel. The tree has the quality to reduce the level of carbon dioxide and hence reduces the level of green house gas (GHG). This kind of projects will give income generation opportunities to the rural/tribal people and in our nations favour resulting successful implementation of mahua oil as substitute to diesel on larger scale that too with non-agricultural land.

\section{FUTURE OF BIODIESEL (NON-EDIBLE OILS) IN INDIA}

India is also well known as agricultural country but it also has the immense potential to produce biodiesel from non-edible oils. Non-edible oils are being produced from the wasteland and as per Government of India did the economic survey, the report says in statistics that about 175 million hectares are marked as waste and degraded land and this gives us the regulator to maintain the supply of feed stocks for the large scale project. We need to erect the mechanism with a certain utilization path which will gear up at national level like other countries are doing across the globe. Industries along with proper government plans have to play an important role in defining a clean supply chain policy which exercises the Life Cycle Analysis on biodiesel production.

\section{CONCLUSION}

With the above results, we can wrap up that mahua tree is very useful, economical and each part is used by the local residents. Leprosy can be cured by using bark mahua and also wounds can be healed. We can collect fresh mahua flowers in the morning and which is financially viable in nature. Using mahua flowers we can prepare many dishes with fresh and dried ones, also one can eat fresh flowers as well. In tribal regions, liquor made of mahua is very famous and could be prepared by doing distillation of dried mahua flowers and its fruit pulp can also be used for preparation of alcohol.

Alcohol from the flowers of mahua capitulates 340 litres per tonne of flowers. These flowers and fruits after segregating pulp could be used as farm stock to cattle's. Its flowers has certain medicinal impacts and tribal's use it to get relief from cardiac diseases, biliousness and throat infections where as its fruit provides medicinal affects in which blood diseases can be cured. Matured fruit is nourishing in nature and can be eaten raw or cooked.

Mahua seeds are of profitable in nature with every aspect like extraction of oil, its oil is also used for skin allergies and for the making of soap and detergents. Mahua seed contains oil which varies from 33-43\% of the weight of kernel. It also reduces the cholesterol level of heart because of linoleic acid. Unfortunately we have scarcity of proper marketing of mahua flowers and seeds to the market that's why it remains only a product of forest with tribal people for local purpose, just a local person is purchasing the same from villagers and supply it to actual market of oil expellers. Table 3 shows the fatty acid composition aspects of many other non edible oils, their properties and characteristics which help us to judge better or best biodiesel. Density, Viscosity, flash point and fire point of mahua oil are on greater side with less calorific value which is in the range of $86 \%$ in comparison with pure diesel.

With these we can think for mahua as fuel oil and our nation has such a vast land area fertile and unfertile. Unfertile land is huge and can be taken for commercialisation of mahua crop so as to get the fuel oil. It has property as good fertilizer and villagers are also drawing oil but commercially it will definitely reduce our dependency on petroleum oils which are imported to meet our nation's demand, also thereby saving lots of foreign exchange to enhance nation's economy. Concluding with all the above facts, it has seen that there are many probabilities to make biodiesel from non edible oil sources which will help us to capitalise the manufacturing of biodiesel. 


\section{REFERENCES}

[1] Ioan S.,On the Future of Biodegradable Vegetable Lubricants Used for Industrial Tribo Systemsl,Gal I Fascicie 2002;VIII:pp 1221-4590.

[2] WilfriedJ. Bartz,-Ecotribology: Environmentally Acceptable Tribological Practicesl, Tribology International, Vol. 39, 2006, pp728-733.

[3] Adhvaryu A, Biresaw, G., Sharma, B.K., Erhan, S.Z., -Friction Behavior of Some SeedOils: Biobased Lubricant Applicationsll, Ind. Eng.Chem. Res. 45, 2006, pp 3735-3740.

[4] Demirbas, A. Biofuels securing the planet's future energy needs. Energy Conversion and Management 2009, 50, 2239-2249.

[5] Bull, S.R. Renewable energy transportation technologies. Renewable Energy 1996, 9, 1019-1024.

[6] Agarwal, A.K. Biofuels (alcohols and biodiesel) applications as fuels for internal combustion engines. Progress in Energy and Combustion Science 2007, 33, 233-271.

[7] Zhou A.; Thomson E. The Development of Biofuels in Asia. Applied Energy 2009, 86, s11-s20.

[8] Quaye, E.C. Energy demands in the 21st century: The Role of Biofuels in a Developing Country. Renewable Energy 1996, 9, 10291032 .

[9] Prabhakar, S.V.R.K.; Elder, M. Biofuels and resource use efficiency in developing Asia: Back to basics, Applied Energy 2009, 86, 3036.

[10] Vandenbroucke, F. Conflicts in international economic policy and the world recession: a theoretical analysis. Camb. J. Econ. 1985, 9, 15-42.

[11] Pomfret, R. Central Asia and the Global Economic Crisis. EU-Central Asia Monitoring (EUCAM) 2009, 7, 1-6.

[12] Tonnesson, S.; Kolas, A. Energy Security in Asia: China, India, Oil and Peace. International Peace Research Institute, Oslo (PRIO) 2006, pp. 92.

[13] Nikitchenko. J. (n.d). Comparative Analysis of Biodiesel and Mineral Diesel Fuel In Case of Use for Urban Buses. Department of Chemmotology, National Aviation University, Kiev. Available: http://rep.bntu.by/bitstream/data/1580/4/257-265.pdf.

[14] Oliveira L. E., Da Silva M. L. C. P. (2013). Comparative study of calorific value of rapeseed, soybean, jatropha curcas and crambe biodiesel. Renewable Energy and Power Quality Journal, 11, 1-4

[15] Aregbe O. A. Biodiesel an Alternative fuel for a Cleaner Environment as Compared to Petroleum Diesel.American University of Nigeria Library, TP 359.B46 A231 2010.

[16] U.S. Energy Information Administration, International Energy Statistics Biofuels Production. Available at http://tonto.eia.gov, last accessed 05.04.12.

[17] Economic Survey 2010-2011 available at http://indiabudget.nic.in, (last accessed 30.01.2012).

[18] US energy Administration. www.eia.gov (last accessed 25.01.2012).

[19] Ministry of external affairs, Govt. of India, available at http://meaindia.nic.in/ (last accessed 05.08.2011).

[20] Transport and communication, 9th Five Year Plan (vol-2), Planning commission of India, Govt. of India, http://planningcomission.gov.in (last accessed 12.09.2011).

[21] Ministry of Commerce and Industry, Government of India, available at http://commere.nic.in/pressrel.html last accessed 10.03.12).

[22] Ministry of Consumer Affairs, Food \& Public Distribution. www.fcamin.nic.in (last accessed 10.04.12).

[23] Erhan, S. Z., Asadauskas, S., Lubricant basestocks from vegetable oilsl, Industrial Crops Production,Vol.11,2000,pp277-282.

[24] Wagner, H., Luther, R., Mang. T., Lubricant Base Fluids Based on Renewable RawMaterialsTheir Catalytic Manufacture and Modificationll,Appl. Catal. A, 2001,Vol.221, pp 429-442.

[25] Sevim, Z. Erhan, Brajendra, K. Sharma, Joseph, M. Perez, Oxidation and Low Temperature Stability of Vegetable Oil-Based Lubricants, Industrial Crops and Products, Vol.24, 2006, pp. 292-299.

[26] Asadauskas, S., Pérez, J.M., Duda, J.L.,Oxidative Stability and Antiwear Properties ofHigh Oleic Vegetable Oilsl, Lubrication Engg Vol.52, 1996, pp877-882.

[27] Emmanuel, O., Allayer, K. O., Obahiagbon, Mudiakeoghene Ori-jesu, -Biodegradation of Vegetable Oils: A review, Scientific Research and Essay, 2009, Vol.4(6), pp543-548.

[28] Shahabuddin,M., Masjuki, S.S., Kalam, M.A., Experimental Investigation in to Tribological Characteristics of Biolubricant Formulated from Jatropha Oil, Procedia Engineering, 2013, Vol.56, pp 597-606.

[29] Singh, A.K., Castor Oil-Based Lubricant Reduces Smoke Emission In Two-Stroke Engines, Industrial Crops and Products, 2011, Vol.33, pp 287-295.

[30] Bekal, S., Bhat N.R., Bio-lubricant as an Alternative to Mineral Oil for a CI Engine-An Experimental Investigation with Pongamia Oil as a Lubricant, Energy Sources, Part A. Taylor \& Francis, 2012, Vol.34, pp 1016-1026.

[31] Jain,A.K., Suhane,A., - Research Approach \& Prospects of Non Edible Vegetable Oil as a Potential Resource for Biolubricant A Review, Advanced Engineering and Applied Sciences Journal, 2012, Vol.1(1), pp 23-32.

[32] Chinchkar,D.S., Satpute,S.T., Kumbhar, N.R. , Castor Oil as Green Lubricant-A Review, International Journal of Engineering Research \& Technology, 2012, Vol. 1 (5), pp13.

[33] Pugazhvadivu, M., Sankaranarayanan, G., Experimental Studies on a Diesel Engine Using Mahua Oil As Fuel, Indian Journal of Science and Technology, 2010, Vol. 3 (7), pp 787-791.

[34] Puhan, S., Vedaraman, N., Rambrahamam, B.V., Nagarjan,G.,Mahua Seed Oil- A Source of Renewable Energy in India, Journal of Scientific \& Industrial Research, 2005, Vol.64, pp890-896.

[35] Saroj K. Padhi and R. K. Singh, Non-edible oils as the potential source for the production of biodiesel in India: A review, J. Chem. Pharm. Res., 2011, 3(2):39-49, ISSN No: 0975-7384 CODEN (USA): JCPRC5. 
IOSR Journal of Mechanical and Civil Engineering (IOSR-JMCE)

e-ISSN: 2278-1684, p-ISSN: 2320-334X

[36] Mahua (Madhuca Indica): The new source of biodiesel, http://www.jatrophabiodiesel.org/Madhuca\%20Indica/index.php.

[37] Janulis, P. Renewable energy, 2004; 29: $861-871$

[38] Edible Oil Refinery Exporters, Manufacturers And Suppliers (INDIA) Chempro Technovation Pvt. Ltd., http://www.chempro.in/fattyacid.htm 